\title{
ULOGA NEFINANCIJSKIH INFORMACIJA \\ U POSLOVNOM ODLUČIVANJU U OVISNOSTI O KARAKTERISTIKAMA PODUZEĆA
}

\author{
ROLE OF NON-FINANCIAL INFORMATION \\ IN BUSINESS DECISION-MAKING PROCESSES \\ DEPENDING ON THE FIRM'S CHARACTERISTICS
}

SAŽETAK: Potreba za društveno odgovornim poslovanjem i transparentnim izvještavanjem učinila je nefinancijske informacije ravnopravnima financijskim informacijama. Informiranost menadžera pri donošenju poslovnih odluka jedan je od ključnih čimbenika koji utječu na kvalitetu poslovnoga odlučivanja. U cilju saznanja kako karakteristike poduzeća i menadžera utječu na transparentnost izvještavanja te shvaćanje važnosti nefinancijskoga izvještavanja, provedeno je empirijsko istraživanje na uzorku poduzeća registriranih u Republici Hrvatskoj. Na temelju rezultata provedenih statističkih testova zaključeno je da srednja i velika poduzeća pridaju veći ponder važnosti nefinancijskih informacija u odnosu na mikro i mala poduzeća. Pored toga, menadžeri na višim hijerarhijskim razinama nefinancijske informacije i transparentno izvještavanje također smatraju statistički značajno važnijima u usporedbi s menadžerima na nižoj hijerarhijskoj razini.

KLJUČNE RIJEČI: nefinancijske informacije, poslovno odlučivanje, transparentno izvještavanje, društvena odgovornost poduzeća.

JEL: M41.

Doc. dr. sc. Nikolina Dečman, Ekonomski fakultet Sveučilišta u Zagrebu, Trg J. F. Kennedyja 6, 10000 Zagreb, e-mail: ndecman@efzg.hr.

** Dr. sc. Andreja Švigir, Altius savjetovanje d.o.o., I. B. Mažuranić 24, 10000 Zagreb, e-mail: andreja. svigir@altius.hr.

**** Ana Rep, mag. oec., Ekonomski fakultet Sveučilišta u Zagrebu, Trg J. F. Kennedyja 6, 10000 Zagreb, e-mail: arep@efzg.hr. 


\begin{abstract}
The need for socially responsible business and transparent reporting has made non-financial information as important as financial information. One of the key factors that influence the quality of business decision making is the awareness of managers who make business decisions. In order to find out how characteristics of a company and managers influence the transparency of reporting and the understanding of importance of non-financial reporting, empirical research has been conducted on a sample of Croatian companies. Based on the results of the statistical tests carried out, it has been concluded that medium and large companies give the higher importance to the non-financial information compared with micro and small enterprises. Furthermore, managers at the middle and top-level of management consider the non-financial information and transparent reporting statistically significantly more important compared with the low-level managers.
\end{abstract}

KEY WORDS: non-financial information, business decision-making, transparent reporting, corporate social responsibility.

JEL: M41.

\title{
1. UVOD
}

Postojanje kvalitetnih informacija pretpostavka je donošenja kvalitetnih poslovnih odluka (Sikavica et al., 1999.). Sve donedavno, informacije sadržane u financijskim izvještajima bile su ključne pri donošenju poslovnih odluka (Gómez, 2019.; Friães dos Santos $e t$ al., 2018.; Berisha Vokshi \& Xhelili Krasniqi, 2017.; Žager \& Žager, 2006.). U posljednje vrijeme postalo je uobičajeno da korisnici pored financijskih informacija sve veći značaj pridaju i nefinancijskim informacijama. Naime, poznavanjem financijskih, organizacijskih, okolišnih i upravljačkih obilježja poduzeća osiguravaju održivost i transparentnost poslovanja (Global Reporting Initiatives, 2019.; Fung, 2014.). Time se postiže bolje razumijevanje društvene odgovornosti poduzeća, a u konačnici korisnici stječu višu razinu povjerenja u postojeće poslovanje i perspektivu razvoja poduzeća u budućnosti.

Suvremeni uvjeti poslovanja zahtijevaju neprestano prilagođavanje promjenama koje se događaju unutar i izvan poduzeća. Nerijetko se ističe kako su „organizacijske promjene ključan uvjet opstanka modernih organizacija“ (Galetić \& Klindžić, 2011.: 365). Štoviše, može se reći kako globalni uvjeti poslovanja traže od menadžmenta kontinuirano usavršavanje kako znanja, tako i vještina, što podrazumijeva permanentan rad na razvoju vlastitih kompetencija. Otvorenost prema promjenama kao i otvorenost prema društveno odgovornom poslovanju (dalje u tekstu: DOP), poželjne su karakteristike suvremenoga menadžmenta koje se očituju kroz razvoj odnosa sa svim interesno-utjecajnim skupinama, brigu za okoliš te cjelokupnu društvenu zajednicu. U cilju saznanja kako karakteristike poduzeća i njegova menadžmenta (veličina poduzeća, hijerarhijska razina menadžera te činjenica sastavlja li poduzeće nefinancijsko izvješće) utječu na transparentnost izvještavanja te percepciju važnosti nefinancijskoga izvještavanja, provedeno je empirijsko istraživanje na uzorku poduzeća registriranih u Republici Hrvatskoj. Konačno, najznačajniji doprinos rada su sveobuhvatni rezultati istraživanja koji zainteresiranoj znanstvenoj i poslovnoj javnosti daju odgovor na pitanje, jesu li poduzeća svjesna važnosti komuniciranja nefinancijskih informacija sa svim dionicima u cilju unaprjeđenja kvalitete i uspješnosti svoga poslovanja. 


\section{PREGLED DOSADAŠNJIH ISTRAŽIVANJA O VAŽNOSTI NEFINANCIJSKIH INFORMACIJA U POSLOVNOM ODLUČIVANJU}

Dugi niz godina financijske informacije su smatrane ključnim izvorom relevantnih informacija za potrebe poslovnoga odlučivanja. Iako nefinancijsko izvještavanje nije novina, zastupljenost nefinancijskih informacija u području izvještavanja eksternih korisnika tek u posljednjih nekoliko godina dobiva na značaju (Hoffmann et al., 2018.; Loprevite et al., 2018.; Sierra-Garcia et al., 2018.; Stolowy \& Paugam, 2018.; Ehnert et al., 2016.). Tome je svakako pridonijela i Direktiva 2014/95/EU koju je Republika Hrvatska kao zemlja članica Europske unije bila obvezna transponirati u nacionalno zakonodavstvo. To je i učinjeno 2016. godine izmjenama Zakona o računovodstvu (NN, 78/15., 134/15., 120/16.), kao temeljnoga akta koji uređuje računovodstvo poduzetnika. U Republici Hrvatskoj trenutno ne postoji obveza sastavljanja integriranoga izvješća koje bi sadržavalo skup financijskih i nefinancijskih informacija, ali su određena poduzeća pored godišnjih financijskih izvještaja, sukladno aktualnom Zakonu o računovodstvu (NN, 78/15., 134/15., 120/16., 116/18.), dužna sastaviti i nefinancijsko izvješće. Naime, zahtijeva se sastavljanje nefinancijskoga izvješća za sve velike poduzetnike koji su subjekti od javnoga interesa i koji na datum bilance prelaze kriterij prosječnoga broja od 500 radnika tijekom prethodne poslovne godine. Sadržaj nefinancijskoga izvješća u potpunosti je usklađen sa zahtjevima Direktive 2014/95/ EU, a obuhvaća informacije nužne za razumijevanje razvoja, poslovnih rezultata i položaja poduzetnika te učinka njegovih aktivnosti koje se odnose najmanje na okolišna, socijalna i kadrovska pitanja, poštovanje ljudskih prava, borbu protiv korupcije i pitanja u vezi s podmićivanjem. Najznačajnija prednost činjenice da je nefinancijsko izvještavanje postalo zakonska obveza može se prepoznati u tome što poduzetnici i dalje zadržavaju pravo izvještavanja samo o onim informacijama koje ne štete njihovu ugledu ni poslovnom položaju. Činjenica da su određena poduzeća dužna sastaviti nefinancijsko izvješće ne mora nužno značiti da ta poduzeća u većoj mjeri shvaćaju važnost nefinancijskih informacija. U cilju saznanja utječe li sastavljanje nefinancijskog izvješća na percepciju važnosti nefinancijskih informacija za svrhe odlučivanja, postavlja se prva istraživačka hipoteza:

H1: Poduzeća koja sastavljaju nefinancijsko izvješće smatraju nefinancijske informacije važnijima u odnosu poduzeća koja takvo izvješće ne sastavljaju.

I dok je prilično jasno što se podrazumijeva pod financijskim informacijama, Direktiva EU 2014/95/EU pod nefinancijskim izvještavanjem podrazumijeva različite informacije o društveno odgovornom poslovanju poduzeća koje obuhvaćaju socijalna, društvena, organizacijska, okolišna i druga pitanja koja za cilj imaju komunicirati korporativnu kulturu te kvalitetu cjelokupnoga poslovanja poduzeća (European Parliament and Council, 2014.). Prema podacima KPMG-a (2017.), izvještavanje o društvenoj odgovornosti poduzeća postaje standardna praksa za srednja i velika poduzeća diljem svijeta. Većina najvećih svjetskih poduzeća danas uključuje niz financijskih i nefinancijskih informacija u svoje godišnje financijske izvještaje. Podatak da čak $78 \%$ poduzeća integrirano izvještava o društvenoj odgovornosti poduzeća potvrđuje relevantnost takvih informacija za investitorsku javnost. (KPMG, 2017.: 4). Naime, dok je „izvješćivanje o održivosti postalo uobičajeno za velike 
i multinacionalne kompanije, među malim i srednjim poduzećima praksa izvještavanja o održivosti i nije tako raširena" (European Federation of Accountants and Auditors for SMEs, 2018.: 5). Podatak da su u 2015. godini mala i srednja poduzeća pripremila svega 10 \% od ukupnoga broja izvješća o održivosti obuhvaćenih u GRI (Global Reporting Initiative) bazi podataka o objavljivanju podataka o održivosti govori u prilog navedenoj tezi (GRI Newsletter, 2016.). Sukladno navedenome, postavlja se druga istraživačka hipoteza:

H2: Postoji pozitivna veza između veličine poduzeća i menadžerske percepcije važnosti nefinancijskih informacija za poslovno odlučivanje.

Pri donošenju poslovnih odluka informiranost menadžmenta jedan je od ključnih čimbenika koji utječu na kvalitetu poslovnoga odlučivanja. Neosporno je kako su za donošenje kvalitetnih i racionalnih poslovnih odluka financijske informacije od posebnoga značaja, međutim dodanu vrijednost svakako nose i nefinancijske informacije. Unatoč tome, pojedina poduzeća obvezu sastavljanja nefinancijskoga izvješća smatraju administrativnim opterećenjem. S druge strane, postoje i ona poduzeća koja su ovoj problematici već i ranije pridavala potrebni značaj te su dobrovoljno objavljivala nefinancijske informacije (Hoffmann, et al. 2018.; Sierra-Garcia, et al., 2018.; Loprevite, et al., 2018.; Sofian \& Dumitru, 2017.; Dečman \& Rep, 2018.). Steinmeier i Stich (2019.) empirijski dokazuju kako izvještavanje o održivosti osigurava kvalitetnu informacijsku podlogu za donošenje poslovnih odluka o upravljanju investicijama. Pored navedenoga, postoje istraživanja koja dokazuju kako kvaliteta financijskoga izvještavanja pozitivno utječe na nefinancijsku uspješnost poduzeća (Al-Dmour et al., 2018.). U teoriji i praksi nerijetko se postavlja pitanje hoće li nefinancijsko izvještavanje pridonijeti financijskom uspjehu poduzeća? Dosadašnja istraživanja uglavnom potvrđuju kako izvještavanje o održivosti i izvještavanje o socijalnoj odgovornosti ima utjecaja na uspješnost poslovanja. Istraživanja koja potvrđuju ovu tezu uglavnom su testirana na uzorku kotirajućih kompanija (Reddy \& Gordon, 2010.; Pizzi, 2018.). S druge strane, postoje istraživanja koja raspravljaju povezanost socijalne i financijske uspješnosti (Garcia-Castro et al., 2009.). Naime, u navedenom istraživanju se polazi od pretpostavke kako postoje različiti rezultati dosada provedenih empirijskih istraživanja. U radu se navodi kako većina autora dokazuje pozitivnu vezu između socijalne i financijske uspješnosti (engl. social performance - SP vs. financial performance - FP), ali ističu kako postoje i ona istraživanja koja negiraju njihov pozitivan odnos. Garcia-Castro et al. (2009.) razloge heterogenosti rezultata istraživanja pronalaze u činjenici kako je moguće da nisu korištene adekvatne mjere i instrumenti pri mjerenju socijalne uspješnosti. Također, ističu kako se odnos SP i FP mijenja s vremenom i u okolnostima koje nisu uvažavane kao kontrolne varijable.

Zaključno, treba istaknuti kako kvalitetna informacijska podloga pretpostavlja poznavanje relevantnih financijskih i nefinancijskih informacija gdje značajan doprinos poslovnom odlučivanju može dati upravo računovodstvena profesija u suradnji s menadžmentom poduzeća. 


\section{IZAZOVI SUVREMENOG MENADŽMENTA U KONTEKSTU POSLOVNOGA ODLUČIVANJA}

Današnji uvjeti poslovanja stavljaju pred menadžment brojne izazove. Osim potrebe neprestanog prilagođavanja promjenama koje se događaju unutar i izvan poduzeća, globalni uvjeti poslovanja traže od menadžera i permanentan rad na vlastitom znanju i kompetencijama. Radi se o kompetencijama važnim za kvalitetno odlučivanje pa time i upravljanje. Da bi menadžment mogao upravljati poduzećem u današnjim, volatilnim uvjetima poslovanja treba biti usmjeren prema stjecanju novih znanja, uporabi digitalne tehnologije koja, između ostaloga, omogućava kreiranje kvalitetnih financijskih informacija, upravljanju ljudima i u konačnici treba biti usmjeren prema DOP-u.

„Informacije su najvažniji resurs na temelju kojega se donose poslovne odluke na svim razinama odlučivanja, od operativnoga preko taktičkoga do strateškoga. Bez kvalitetnih informacijskih sustava koji reproduciraju jednako kvalitetne informacije za poslovno odlučivanje, uspješan ishod poslovnih odluka stvar je slučajnosti“ (Švigir, 2018.: 24). Informacije su u podlozi svakoga procesa donošenja odluka. Operativne odluke u pravilu su ponavljajuće tako da je operativno odlučivanje primarno povezano s racionalnošću. $\mathrm{S}$ druge pak strane, za strateške odluke potrebno je prethodno iskustvo tako da se strateške odluke primarno donose na temelju intuicije. Iako se operativno i strateško odlučivanje razlikuju po sadržaju i procesu, važno je naglasiti da je kvalitetna informacija u temelju i operativnih i strateških odluka. Stoga je izgradnja informacijskoga sustava koji omogućava dolazak do kvalitetnih informacija neophodna kako bi odluke koje se donose bile učinkovite i poduzeće vodile prema postavljenom cilju. „Činjenica da se u poduzećima u Republici Hrvatskoj odluke donose primarno racionalno i da se temelje na brojevima te da se tako donesene odluke smatraju i kvalitetnijima u odnosu na intuitivne, znači da je izgradnja informacijskog sustava koji će omogućiti dolazak do kvalitetnih informacija neophodna kako bi odluke koje se donose bile učinkovite te poduzeće vodile do željenog cilja“ (Švigir, 2018.: 282). Usmjerenost menadžmenta na operativno odlučivanje istovremeno ukazuje i na njegov odmak od strateškoga pogleda na poslovanje. Time se može zaključiti da će razvoj i unaprjeđenje kompetencija koje su menadžmentu potrebne za upravljanje primarno biti povezani s onima koje su nužne za operativno poslovanje i vođenje poduzeća. U tom smislu može se ukazati na određene nedostatke u kompetencijama koje mogu ugroziti dugoročnu uspješnost poslovanja. Iako menadžment smatra da su za poslovno upravljanje nefinancijske informacije važnije od financijskih ipak se još uvijek u poslovnom odlučivanju pa time i upravljanju više oslanjaju na financijske informacije (Švigir, 2018.: 334). U ovisnosti o razini kojoj menadžer pripada, postavljena je treća istraživačka hipoteza:

H3: Postoji statistički značajna razlika u stavovima menadžera na nižim i višim hijerarhijskim razinama o važnosti nefinancijskih informacija i transparentnosti izvještavanja za poslovno odlučivanje.

Nadalje, menadžment globalne ekonomije obilježava njegova otvorenost prema DOP-u. „Na tržištu 21. stoljeća, poduzeća sve više pokazuju znakove svjesnosti o važnosti primjene etike kao i društvene odgovornosti u poslovanju“ (Kanji \& Chopra, 2010.: 119). DOP, osim što unaprjeđuje odnos sa zaposlenicima, vodi računa o okolišu, ali i cjelokupnoj 
društvenoj zajednici. „Temeljne vrijednosti koje određuju ono što je ispravno i poželjno ponašanje organizacije, često su jedino vezivno tkivo i čvrsto uporište u mnoštvu različitih oblika ponašanja, odluka i kompleksnih odnosa koje nameće suvremeno poslovanje“ (Bahtijarević-Šiber et al., 2008.: 531). U literaturi se ističe kako se „razlozi sve veće raširenosti društveno odgovornoga poslovanja mogu pronaći u motivima altruističke i ekonomske prirode“ (Rašić, 2011: 462). Onaj menadžment koji je svjestan važnosti DOP-a i koji ga primjenjuje u poslovanju može očekivati stabilan rast i razvoj poduzeća. Unatoč toj činjenici, mnoga poduzeća ne smatraju da je DOP bitna odrednica njihove uspješnosti pa ga neprestano zanemaruju. „Poduzeća u Hrvatskoj imaju naznake DOP-a, ali u isto vrijeme nemaju sustavnu strategiju na kojoj bi bazirala takav način poslovanja. Često se fokusiraju samo na jedan segment društvene odgovornosti, zaboravljajući svu kompleksnost spomenutog koncepta“" (Vrdoljak Raguž \& Hazdovac, 2014.: 40).

Budućnost upravljanja poduzećima obuhvaća sve više odrednica koje nisu usmjerene samo na unaprjeđenje i razvoj unutarnjih čimbenika odgovornih za uspješnost poslovanja. Sve je više vanjskih čimbenika koji pred menadžment poduzeća postavljaju izazove na koje će menadžment biti u mogućnosti odgovoriti isključivo razvojem vlastitih kompetencija. „Poduzeća sve više uočavaju važnost svoje uloge u održivom razvoju te svojim promicanjem društveno odgovornog poslovanja teže postići zadovoljavajuću ravnotežu između ekonomskog aspekta svoje poslovne prakse te odnosa prema okolišu i društvu“ (Osagie et al., 2016: 234). „Nove paradigme traže od menadžmenta kontinuiranu edukaciju i razvoj kompetencija. Integrativan način promišljanja o poslovanju koji u konačnici rezultira i integrativnim sustavom izvještavanja, donosi u poslovni svijet sustav upravljanja čiji su ciljevi održivi razvoj i društveno odgovorno poslovanje. Tako određeni ciljevi u funkciji su boljitka svih interesno utjecajnih skupina pa time i društva u cjelini““ (Švigir, 2016.: 139).

Upravo cjeloviti pristup upravljanju poduzećem koji osim financijskih koristi i mnoštva nefinancijskih informacija postaje imperativ upravljanja u globalnoj ekonomiji. On u razmatranje osim financijske uspješnosti poduzeća uključuje i izgradnju kvalitetnih odnosa sa svim interesno-utjecajnim skupinama. Radi se o neprestanom dijalogu koji vodi prema razvoju partnerskih odnosa, uspješnom poslovanju te u konačnici dobrobiti cjelokupne društvene zajednice. Ovaj dijalog uspostavlja se upravo kroz kreiranje i korištenje nefinancijskih informacija koje postaju sve značajnije za odlučivanje pa time i upravljanje poduzećima.

Srednja i velika poduzeća u Republici Hrvatskoj kao i menadžeri viših razina svjesni su važnosti primjene društveno odgovornog poslovanja kao i važnosti unaprjeđenja etičke poslovne prakse. S druge pak strane, mikro i mala poduzeća kao i menadžeri niže razine najčešće ne polažu dovoljno pozornosti nefinancijskom izvještavanju. Razlog ovakve percepcije svakako proizlazi i iz zakonskih odredbi koje velikim poduzećima od javnoga interesa nalažu sastavljanje nefinancijskoga izvješća, dok ostala poduzeća takvu obvezu nemaju. Unatoč tome preporuka Direktive EU 2014/95/EU je da nefinancijsko izvješće sastavljaju sva poduzeća bez obzira na svoju veličinu te je u tom kontekstu potrebno neprestano raditi na podizanju razine znanja, ali i svjesnosti o važnosti nefinancijskih informacija za poslovno upravljanje. 


\section{EMPIRIJSKO ISTRAŽIVANJE}

\subsection{Metodologija istraživanja}

Empirijsko istraživanje provedeno je korištenjem anketnoga upitnika koji je bio distribuiran poduzećima iz realnoga sektora. Istraživanje je provedeno tijekom ožujka 2019. godine te je prikupljeno 63 potpuno ispunjenih anketnih upitnika. S obzirom na odredbe Zakona o provedbi Opće uredbe o zaštiti podataka (NN, 42/18.), istraživački uzorak bio je prigodan, a činili su ga ispitanici s kojima je već ranije ostvaren kontakt (3.000 poduzeća). Prvi dio istraživačkoga upitnika sadržavao je pitanja vezana uz obilježja poduzeća u kojem ispitanik radi, dok je drugi dio upitnika sadržavao tvrdnje vezane uz nefinancijsko izvještavanje koje su formirane u obliku Likertove skale s 5 razina odgovora. Tvrdnje sadržane u drugom dijelu upitnika izvorno su oblikovane od strane autora, a odnose se na relevantna područja računovodstvenih politika i procedura korištenih prilikom nefinancijskoga izvještavanja. Pri ispitivanju istraživačkih hipoteza promatrane su tri nezavisne karakteristike poduzeća iz uzorka (veličina poduzeća, hijerarhijska razina menadžera te činjenica je li poduzeće sastavilo nefinancijsko izvješće). Metodama deskriptivne i inferencijalne statistike testirani su i analizirani rezultati kako bi se metodom dedukcije donijeli zaključci.

Predmet analize bila su poduzeća iz „nefinancijskoga poslovnog gospodarstva“ koja prema Državnom zavodu za statistiku (2018.) čine najveći udio tzv. realnoga sektora (industrija, građevinarstvo, trgovina i nefinancijske usluge). Poduzeća u kojima je zaposlen najveći udio ispitanika, njih $37 \%$ bave se pružanjem nefinancijskih usluga, $33 \%$ pripada djelatnostima industrije, $19 \%$ djelatnostima trgovine i $11 \%$ djelatnostima građevinarstva. $\mathrm{U}$ istraživanju je sudjelovalo $51 \%$ ispitanika koji rade u mikro i malim i $49 \%$ ispitanika koji rade u srednjim i velikim poduzećima. Nadalje, $79 \%$ ispitanika zaposleno je u poduzećima koja zapošljavaju do 500 zaposlenika, dok preostali ispitanici pripadaju poduzećima s više od 500 zaposlenika. S obzirom da je $44 \%$ ispitanika odgovorilo kako je njihovo poduzeće sastavilo nefinancijsko izvješće za 2017. godinu, zaključuje se kako i poduzeća koja nisu obveznici izrade nefinancijskoga izvješća, prema odredbama Zakona o računovodstvu, takvo izvješće sastavljaju. $78 \%$ poduzeća ima interno organiziranu funkciju odnosno odjel računovodstva, dok se $22 \%$ poduzeća iz uzorka koristi uslugom outsourcinga odnosno angažiraju vanjski računovodstveni servis u svrhu vođenja poslovnih knjiga. S aspekta razine menadžmenta kojoj pripadaju ispitanici, njih $45 \%$ odgovorilo je da pripadaju nižoj razini menadžmenta, $30 \%$ pripada srednjoj razini, a preostalih $25 \%$ pripada visokoj razini menadžmenta.

\subsection{Deskriptivna analiza rezultata istraživanja}

Prije provedbe složenije analize, provedena je deskriptivna analiza odgovora koje su dali ispitanici. Za potrebe ispitivanja prve i druge istraživačke hipoteze, tvrdnje koje su korištene za usporedbu i mjere deskriptivne statistike prikazane su u tablici 1. Na skali od jedan do pet (od u potpunosti se ne slažem do u potpunosti se slažem) ispitanici su izrazili svoje mišljenje u vezi važnosti nefinancijskih informacija. 
Tablica 1. Mjere deskriptivne statistike za tvrdnje o važnosti nefinancijskih informacija

\begin{tabular}{|l|c|c|c|}
\hline & $\begin{array}{c}\text { Prilikom } \\
\text { donošenja odluka } \\
\text { nefinancijske } \\
\text { informacije često } \\
\text { postaju važnije } \\
\text { od financijskih } \\
\text { (računovodstvenih- } \\
\text { povijesnih). }\end{array}$ & $\begin{array}{c}\text { Prilikom } \\
\text { izvještavanja } \\
\text { informovodstvene } \\
\text { potrebno je } \\
\text { potkrijepiti } \\
\text { nefinancijskim } \\
\text { informacijama. }\end{array}$ & $\begin{array}{c}\text { Informacije } \\
\text { o pitanjima } \\
\text { vezanima uz } \\
\text { okoliš, zaposlenike, } \\
\text { društvenu } \\
\text { zajednicu, } \\
\text { ljudska prava } \\
\text { i antikorupciju } \\
\text { trebaju biti sastavni } \\
\text { dio nefinancijskoga } \\
\text { izvješća. }\end{array}$ \\
\hline Mean & 3,44444 & 3,87302 & 3,77778 \\
\hline Median & 3 & 4 & 4 \\
\hline Mode & 3 & 4 & 4 \\
\hline Standard Deviation & 0,89403 & 1,03942 & 1,03868 \\
\hline Sample Variance & 0,79928 & 1,08039 & 1,07885 \\
\hline Sum & 217 & 244 & 238 \\
\hline Count & 63 & 63 & 63 \\
\hline
\end{tabular}

Izvor: izrada autorica.

Prema podacima iz tablice može se zaključiti kako većina ispitanika nefinancijske informacije smatra značajnima s obzirom da srednje vrijednosti za sve tri postavljene tvrdnje prelaze srednju vrijednost od tri. Mjere deskriptivne statistike izračunate su uz razinu od $95 \%$ pouzdanosti procjene. S obzirom da koeficijent varijacije za navedene tvrdnje redom iznosi 25,96 \%,26,84 \% i 27,49 \%, između odgovora svih ispitanika zajedno ne uočava se izražena disperzija. Postoji li, s druge strane, razlika između odgovora koje su dali ispitanici mikro i malih u odnosu na srednja i velika poduzeća, kao i razlika između odgovora ispitanika čije poduzeće sastavlja nefinancijsko izvješće i odgovora koje su dali ispitanici čije poduzeće ne sastavlja nefinancijsko izvješće, ispitano je u sljedećem poglavlju primjenom metoda inferencijalne statistike.

Prilikom ispitivanja treće istraživačke hipoteze, uz tvrdnje iz tablice 1., korištene su i tvrdnje koje su s rezultatima deskriptivne statistike prikazane u tablici 2. Tvrdnje se odnose na važnost i transparentnost nefinancijskoga izvještavanja. 
Tablica 2. Mjere deskriptivne statistike za tvrdnje o važnosti i transparentnosti nefinancijskoga izvještavanja

\begin{tabular}{|l|r|r|r|r|}
\hline & $\begin{array}{c}\text { Za donošenje odluka } \\
\text { o investiranju } \\
\text { investitorima su još } \\
\text { uvijek relevantnije } \\
\text { financijske } \\
\text { (računovodstvene) } \\
\text { informacije.* }\end{array}$ & $\begin{array}{c}\text { Poduzeće bi } \\
\text { trebalo objaviti i } \\
\text { one nefinancijske } \\
\text { informacije } \\
\text { koje govore o } \\
\text { poteškoćama } \\
\text { s kojima se } \\
\text { poduzeće suočava. }\end{array}$ & $\begin{array}{c}\text { Poduzeće ne } \\
\text { bi trebalo } \\
\text { objavljivati } \\
\text { informacije } \\
\text { koje bi mu u } \\
\text { budućnosti } \\
\text { mogle } \\
\text { naštetiti.* }\end{array}$ & $\begin{array}{c}\text { Transparentno } \\
\text { izvještavanje } \\
\text { ključno je za } \\
\text { povjerenje } \\
\text { investitora. }\end{array}$ \\
\hline Mean & 3,96825 & 3,63492 & 3,20635 & 4,1111 \\
\hline Median & 4 & 4 & 4 & 5 \\
\hline Mode & 4 & 1,02078 & 0,98634 & 1,03349 \\
\hline $\begin{array}{l}\text { Standard } \\
\text { Deviation }\end{array}$ & 0,96667 & 1,04199 & 0,97286 & 1,06810 \\
\hline $\begin{array}{l}\text { Sample } \\
\text { Variance }\end{array}$ & 0,93446 & 229 & 202 & 63 \\
\hline Sum & 63 & 63 & 63 & 5 \\
\hline Count & 250 & 4 & & 5 \\
\hline
\end{tabular}

*Primijenjena je inverzna skala odgovora $(1=5, \ldots .5=1)$.

Izvor: izrada autorica.

Analizom odgovora ispitanika i za ove tvrdnje se može zaključiti kako većina ispitanika pridaje važnost značaju i transparentnosti nefinancijskoga izvještavanja s obzirom da su srednje vrijednosti veće od tri. Ispitanici su se u najvećoj mjeri složili s tvrdnjom da je transparentno izvještavanje ključno za povjerenje investitora pri čemu su se najčešce izjasnili da se u potpunosti slažu. Budući da se koeficijent korelacije za sve navedene tvrdnje kreće između $24 \%$ i $31 \%$ zaključuje se kako među odgovorima ispitanika ne postoje značajna odstupanja. Postoji li statistički značajna razlika među odgovorima ispitanika na tvrdnje iz tablice 1. i 2. u ovisnosti o razini menadžmenta dodatno je ispitano primjenom metoda inferencijalne statistike u sljedećem poglavlju.

\subsection{Testiranje istraživačkih hipoteza $i$ analiza rezultata istraživanja}

Prije odabira samih statističkih testova, tvrdnje korištene za ispitivanje svake od pojedinih hipoteza podijeljene su u skupine tako da čine podatke Likertove skale. S obzirom na to, prikladni statistički testovi za testiranje postavljenih hipoteza su ANOVA test, t-test i regresijska analiza (parametarski testovi za normalne distribucije) odnosno Mann-Whitney U test (neparametarski test za distribucije koje nemaju obilježja normalnoga oblika). Temeljem normalnosti distribucija dviju nezavisnih varijabli odabran je odgovarajući test za testiranje svake postavljene hipoteze. S obzirom da je za potrebe testiranja prve hipoteze ispitanike bilo potrebno podijeliti na one čije je poduzeće sastavilo nefinancijsko izvješće i one čije poduzeće nije sastavilo nefinancijsko izvješće, tako su promatrane i distribucije njihovih odgovora. p-vrijednost izračunata na temelju Jarque-Bera testa (Jarque \& Bera, 1987.) za distribuciju vjerojatnosti odgovora ispitanika koji su potvrdno odgovorili na pi- 
tanje o sastavljanju nefinancijskoga izvještaja iznosi 0,049. Iako je empirijska vrijednost tek neznatno manja od teorijske vrijednosti $(0,05)$, hipoteza da je distribucija normalnoga oblika ne može se prihvatiti sa sigurnošću. Prema tome, zaključuje se da podaci nisu normalno distribuirani uz razinu signifikantnosti od $5 \%$, iako ta distribucija ne mora narušiti rezultate parametarskih testova. $\mathrm{S}$ druge strane, $\mathrm{p}$-vrijednost provedenoga Jarque-Bera testa za distribuciju vjerojatnosti odgovora ispitanika koji su odgovorili da njihovo poduzeće nije sastavilo nefinancijsko izvješće za 2017. godinu iznosi 0,337. Nulta hipoteza se ne može odbaciti odnosno zaključuje se kako je uz razinu signifikantnosti od $5 \%$ distribucija podataka normalnoga oblika. Budući da se sumnja u normalnost distribucije vjerojatnosti podataka prve skupine ispitanika potrebno je provesti neparametarske testove u daljnjoj analizi.

Kako bi se ispitala prva istraživačka hipoteza odnosno usporedila dva nezavisna uzorka, korišten je Mann-Whitney U neparametarski test sume rangova. To je test koji predstavlja ekvivalent parametarskom t-testu, primjeren je za ordinalne mjerne skale i uzorci koji se promatraju ne moraju biti jednake veličine (prema Weaver et al., 2017.: 297-298.). Formula prema kojoj su izračunate vrijednosti testa glasi:

$$
\begin{gathered}
U_{1}=n_{1} n_{2}+\frac{n_{1}\left(n_{1}+1\right)}{2}-R_{1} \quad U_{2}=n_{1} n_{2}+\frac{n_{2}\left(n_{2}+1\right)}{2}-R_{2} \\
U=\min \left(U_{1}, U_{2}\right)
\end{gathered}
$$

gdje je:

$n_{1}=$ veličina uzorka 1 (ispitanici koji su sastavili nefinancijsko izvješće)

$n_{2}=$ veličina uzorka 2 (ispitanici koji nisu sastavili nefinancijsko izvješće)

$R_{1}=$ zbroj sume rangova uzorka 1

$R_{2}=$ zbroj sume rangova uzorka 2 .

Rezultati provedenoga testa prikazani su u tablici 3.

Tablica 3. Rezultati Mann-Whitney U testa za potrebe 1. istraživačke hipoteze

\begin{tabular}{|l|r|}
\hline$U_{1}$ & 4275 \\
\hline$U_{2}$ & 4545 \\
\hline$\alpha$ & 0,05 \\
\hline$U_{\text {_statistic }}$ & 4275 \\
\hline Mean & 4410 \\
\hline Variance & 139650 \\
\hline Standard Deviation & 373,6977388 \\
\hline Z-score & $-0,361254527$ \\
\hline U_critical & 3795,271919 \\
\hline p-value & 0,358954592 \\
\hline significance & no \\
\hline
\end{tabular}

Izvor: izračun autorica. 
S obzirom da je empirijska vrijednost provedenoga testa veća od kritične vrijednosti odnosno p-vrijednost je veća od 0,05 , uz razinu signifikantnosti od $5 \%$ ne može se odbaciti nulta hipoteza, što znači da ne postoji statistički značajna razlika između ovih dviju skupina ispitanika. Iako menadžeri čije poduzeće sastavlja nefinancijsko izvješće to izvješće smatraju važnijim (mean $=3,988)$ u odnosu na ispitanike čije poduzeće ne sastavlja nefinancijsko izvješće (mean $=3,467)$, ta razlika nije statistički značajna.

S obzirom da je distribucija podataka iz prvoga uzorka gotovo beznačajno odstupala od normalne, iz toga je uzorka izuzet jedan ispitanik koji je smatran izdvojenicom (engl. outlier) te je ponovno testirana normalnost distribucije. Prema novom testu distribucija je poprimila normalan oblik te je za potrebe testiranja prve hipoteze dodatno proveden i parametarski t-test.

Kako bi se primijenio ispravan t-test prije svega je potrebno provjeriti razlikuju li se varijance uzoraka koji se uspoređuju. Za potrebe testiranja jednakosti varijanci primijenjen je F-test uz razinu signifikantnosti od $5 \%$. Postavljene hipoteze glase:

$$
\begin{aligned}
& \mathrm{H}_{0}: \sigma_{1}^{2}=\sigma_{2}^{2} \\
& \mathrm{H}_{1}: \sigma_{1}^{2} \neq \sigma_{2}^{2}
\end{aligned}
$$

Rezultati provedenoga testa prikazani su u tablici 4. S obzirom da je empirijska F-vrijednost manja od kritične F-vrijednosti odnosno p-vrijednost je veća od 0,05 , uz razinu značajnosti od $5 \%$ nulta hipoteza se ne može odbaciti, što znači da se može smatrati da su varijance ovih dvaju uzoraka jednake. S obzirom na taj zaključak proveden je dvosmjerni t-test homogenih varijanci.

Tablica 4. Rezultati F-testa za potrebe 1. istraživačke hipoteze bez izdvojenica

\begin{tabular}{|l|r|r|}
\hline F-Test Two-Sample for Variances \\
\hline & \multicolumn{1}{|c|}{$N e$} & \multicolumn{1}{c|}{$D a$} \\
\hline Mean & 3,466666667 & 4,049383 \\
\hline Variance & 1,001282051 & 0,797531 \\
\hline Observations & 105 & 81 \\
\hline df & 104 & 80 \\
\hline F & 1,255477495 & \\
\hline P(F<=f) & 0,143829784 & \\
\hline F Critical & 1,422403873 & \\
\hline
\end{tabular}

Izvor: izračun autorica.

Prilikom provođenja dvosmjernoga t-testa postavljene su sljedeće hipoteze (prema Dumičić, Čeh Časni \& Palić, 2016.: 339):

$$
\begin{aligned}
& \mathrm{H}_{0}: \mu_{1}-\mu_{2}=D_{0} \\
& \mathrm{H}_{1}: \mu_{1}-\mu_{2} \neq D_{0}
\end{aligned}
$$

Rezultati provedenoga testa prikazani su u tablici 5. 
Tablica 5. T-test pretpostavljenih jednakih varijanci za testiranje 1 . hipoteze bez izdvojenica

\begin{tabular}{|l|r|r|}
\hline \multicolumn{2}{|l|}{ t-Test: Two-Sample Assuming Equal Variances } & \\
\hline Mean & $D a$ & $N e$ \\
\hline Variance & 4,049382716 & 3,466666667 \\
\hline Observations & 0,797530864 & 1,001282051 \\
\hline Pooled Variance & 81 & 105 \\
\hline Hypothesized Mean Difference & 0,912694579 & \\
\hline df & 0 & \\
\hline $\mathrm{t}$ Stat & 184 & \\
\hline $\mathrm{P}(\mathrm{T}<=\mathrm{t})$ one-tail & 4,12453441 & \\
\hline $\mathrm{t}$ Critical one-tail & $2,80955 \mathrm{E}-05$ & \\
\hline $\mathrm{P}(\mathrm{T}<=\mathrm{t})$ two-tail & 1,653177088 & \\
\hline $\mathrm{t}$ Critical two-tail & $5,61911 \mathrm{E}-05$ & \\
\hline
\end{tabular}

Izvor: izračun autorica.

Budući da je empirijska t-vrijednost veća od kritične t-vrijednosti i ovim se testom dolazi do istoga zaključka kao i primjenom neparametarskoga testa. Iako ispitanici čije je poduzeće sastavilo nefinancijsko izvješće u prosjeku to izvješće smatraju značajnijim u odnosu na one ispitanike čije poduzeće nije sastavilo to izvješće, uz razinu signifikantnosti od $5 \%$ ta razlika nije statistički značajna. Temeljem postavljene hipoteze dolazi se do zaključka kako svi menadžeri nefinancijsko izvješće smatraju podjednako važnim.

Pri testiranju druge hipoteze odgovori ispitanika podijeljeni su na odgovore mikro i malih te srednjih i velikih poduzeća. Primjenom Jarque-Bera testa ispitana je normalnost distribucija obaju skupina odgovora. Distribucija odgovora mikro i malih poduzeća je normalnoga oblika s obzirom da je vrijednost Jarque-Bera testa iznosila 1,009 (p-vrijednost $0,604)$, dok je s druge strane distribucija odgovora srednjih i velikih poduzeća pozitivno asimetrična s vrijednošću Jarque-Bera testa 6,954 (p-vrijednost 0,031). S obzirom da nisu obje distribucije odgovora normalnoga oblika, za testiranje postavljene hipoteze korišten je Mann-Whitney U neparametarski test. Rezultati provedenoga testa prikazani su u tablici 6.

Tablica 6. Rezultati Mann-Whitney U testa za potrebe 2. istraživačke hipoteze

\begin{tabular}{|l|r|}
\hline$U_{1}$ & 7269 \\
\hline$U_{2}$ & 1659 \\
\hline$\alpha$ & 0,05 \\
\hline$U_{\text {__statistic }}$ & 1659 \\
\hline Mean & 4464 \\
\hline Variance & 141360 \\
\hline Standard Deviation & 375,9787228 \\
\hline z-score & $-7,46052856$ \\
\hline U_critical & 3845,520034 \\
\hline p-value & $4,3088 \mathrm{E}-14$ \\
\hline significance & yes \\
\hline
\end{tabular}

Izvor: izračun autorica. 
S obzirom da je empirijska vrijednost provedenoga testa manja od kritične vrijednosti $(1.659<3.845,52)$ odnosno p-vrijednost je manja od 0,05, uz razinu signifikantnosti od $5 \%$, zaključuje se kako srednja i velika poduzeća pridaju statistički značajno veći značaj nefinancijskim informacijama u odnosu na mikro i mala poduzeća. Prema tome, druga hipoteza je potvrđena odnosno veličina poduzeća pozitivno utječe na percepciju važnosti nefinancijskih informacija.

Za potrebe ispitivanja treće hipoteze promatrane tvrdnje mogu se podijeliti u dvije skupine (važnost nefinancijskih informacija i transparentno izvještavanje). S obzirom da su obje skupine uključene u postavljenu istraživačku hipotezu prikladni statistički testovi u osnovi se ne razlikuju u odnosu na već korištene testove. Kao i prilikom testiranja normalnosti uzoraka u prvoj i drugoj hipotezi, i ovdje se zaključuje kako su podaci jednoga uzorka (niža razina menadžmenta) normalno distribuirani, dok podaci drugoga uzorka (više razine menadžmenta) ne prikazuju distribuciju normalnoga oblika.

Za testiranje treće hipoteze ponovno je korišten Mann-Whitney U test kojim se uspoređuje povezanost sume rangova dvaju nezavisnih uzoraka. Prema rezultatima provedenoga testa (tablica 7.), nulta hipoteza se odbacuje budući da je empirijska vrijednost U testa (15.112) manja od kritične vrijednosti U testa $(21.822,4)$ odnosno p-vrijednost je manja od 0,05 . Prema tome, uz razinu signifikantnosti od $5 \%$ može se zaključiti kako menadžeri na višim razinama nefinancijske informacije i transparentno izvještavanje smatraju statistički značajno važnijima u odnosu na menadžere na nižoj razini. Time je treća istraživačka hipoteza potvrđena.

Tablica 7. Rezultati Mann-Whitney U testa za potrebe 3. istraživačke hipoteze

\begin{tabular}{|l|r|}
\hline$U_{1}$ & 32908 \\
\hline$U_{2}$ & 15112 \\
\hline$\alpha$ & 0,05 \\
\hline$U_{-}$statistic & 15112 \\
\hline Mean & 24010 \\
\hline Variance & 1768737 \\
\hline Standard Deviation & 1329,939 \\
\hline z-score & $-6,69053$ \\
\hline U_critical & 21822,4 \\
\hline p-value & $1,11 \mathrm{E}-11$ \\
\hline significance & yes \\
\hline
\end{tabular}

Izvor: izračun autorica.

Svako istraživanje ima svojevrsna ograničenja koja bi se budućim istraživanjima mogla unaprijediti. Prije svega, istraživanje bi se moglo provesti na većem uzorku ispitanika i kroz duže vremensko razdoblje kako bi se prikupilo više odgovora, što bi unaprijedilo snagu statističkih testova. Pored toga, analizom sadržaja nefinancijskih izvještaja moglo bi se provesti istraživanje razine objavljivanja određenih nefinancijskih podataka kako bi 
se dobio uvid u stvarno stanje objavljenih nefinancijskih informacija. Ovo istraživanje je provedeno na uzorku hrvatskih poduzeća. Rezultate ovoga istraživanja bilo bi zanimljivo usporediti s rezultatima istraživanja o važnosti nefinancijskoga izvještavanja u razvijenijim i manje razvijenim zemljama u regiji.

\section{ZAKLJUČAK}

Za donošenje ispravnih poslovnih odluka, pored financijskih informacija, nužno je u obzir uzeti i nefinancijske informacije kojima se zaokružuje cijela slika o poslovanju poduzeća. Može se reći kako velika poduzeća u Republici Hrvatskoj shvaćaju važnost društveno odgovornoga poslovanja te da postoji praksa izvještavanja o održivosti i društvenoj odgovornosti, što ta poduzeća čini usporedivima s multinacionalnim kompanijama odnosno njihovim sustavom izvještavanja.

Pretpostavka kvalitete izvještavanja odnosno kvalitetnih informacija sadržanih u financijskim i nefinancijskim izvještajima svakako je svjesnost menadžmenta o važnosti transparentnoga izvještavanja prema dionicima poduzeća. U empirijskom dijelu ovoga rada testirane su pretpostavke o povezanosti određenih karakteristika poduzeća s percepcijom važnosti nefinancijskih informacija i transparentnoga izvještavanja. Testovima inferencijalne statistike testirane su postavljene hipoteze. Istraživanje je pokazalo da se, uz razinu signifikantnosti od $5 \%$, može zaključiti kako menadžeri na višim razinama menadžmenta kao i srednja i velika poduzeća nefinancijske informacije i transparentno izvještavanje smatraju statistički značajno važnijima za svrhe poslovnog odlučivanja u odnosu na menadžere na nižoj razini odnosno u odnosu na mikro i mala poduzeća. S druge strane, iako menadžeri poduzeća koja sastavljaju nefinancijsko izvješće smatraju nefinancijske informacije značajnijima u odnosu na menadžere onih poduzeća koja ne sastavljaju nefinancijsko izvješće, ta razlika nije se pokazala statistički značajnom uz razinu signifikantnosti od $5 \%$.

Temeljem rezultata provedenoga istraživanja može se zaključiti kako su poduzeća u Republici Hrvatskoj svjesna važnosti transparentnoga objavljivanja kako financijskih, tako i nefinancijskih informacija, ali svakako treba ustrajati na širenju svijesti o važnosti i poboljšanju takvoga izvještavanja te na mogućoj integraciji financijskih i nefinancijskih izvještaja u sustavno i sveobuhvatno integrirano izvješće.

\section{LITERATURA}

1. Al-Dmour, A. H., Abbod, M., \& Al Qadi, N. S. (2018). The impact of the quality of financial reporting on non-financial business performance and the role of organizations demographic' attributes (type, size and experience). Academy of Accounting and Financial Studies Journal, 22(1), 1-18.

2. Bahtijarević-Šiber, F., Sikavica, P., \& Pološki Vokić, N. (2008). Suvremeni menadžment. Zagreb: Školska knjiga.

3. Berisha Vokshi, N., \& Xhelili Krasniqi, F. (2017). Role of Accounting Information in Decision-Making Process, the Importance for its Users. 2017 ENTRENOVA Con- 
ference Proceedings. Dostupno na: https://papers.ssrn.com/sol3/papers.cfm?abstract_ $\mathrm{id}=3282577$ (pristupano 17. svibnja 2019.).

4. Dečman, N., \& Rep, A. (2018). Do Croatian companies recognize benefits of integrated reporting?. Zagreb International Review of Economics and Business, 21, Special Conference Issue, 31-42. DOI: 10.2478/zireb-2018-0022.

5. Državni zavod za statistiku (2018). Osnovni strukturno-poslovni pokazatelji poduzeća u 2017. - privremeni podaci. Dostupno na: https://www.dzs.hr/Hrv_Eng/publication/2018/15-01-01_01_2018.htm (pristupano 25. ožujka 2019.).

6. Dumičić, K., Čeh Časni, A., \& Palić, I. (2016). Odnos parametara dviju populacija: Test hipoteza o pretpostavljenoj razlici aritmetičkih sredina nezavisnim uzorcima. U: Bahovec, V., \& Erjavec, N., ur., Statistika. 2. izdanje. Zagreb: Element, 325-368.

7. European Federation of Accountants and Auditors for SMEs (2018). Survey of Non-Financial Reporting Requirements for SMEs in Europe. Dostupno na: http:// www.efaa.com/cms/upload/efaa_files/pdf/News/20181119_NFRbySMEsReport-FINAL.pdf (pristupano 17. svibnja 2019.).

8. Ehnert, I., Parsa, S., Roper, I., Wagner, M., \& MullerCamen, M. (2016). Reporting on sustainability and HRM: a comparative study of sustainability reporting practices by the world's largest companies. The International Journal of Human Resource Management, 27(1), 88-108. DOI: 10.1080/09585192.2015.1024157.

9. European Parliament and Council (2014). Directive 2014/95/EU of the European Parliament and of the Council of 22 October 2014 amending Directive 2013/34/EU as regards disclosure of non-financial and diversity information by certain large undertakings and groups. Official Journal of the European Union, L 330.

10. Friães dos Santos, J. P., Martins Pires, A. M., \& Fernandes, P. O. (2018). The importance to financial information in the decision-making process in company's family structure. Contaduría y Administración, 63(2), 1-23. DOI: 10.22201/ fca.24488410e.2018.1727.

11. Fung, B. (2014). The Demand and Need for Transparency and Disclosure in Corporate Governance. Universal Journal of Management, 2(2), 72-80. DOI: 10.13189/ ujm.2014.020203.

12. Galetić, L., \& Klindžić, M. (2011). Organizacijske promjene i inovacije: Pojam i određenje organizacijskih promjena. U: Galetić, L., ur., Organizacija velikih poduzeća. Zagreb: Sinergija-nakladništvo, 363-399.

13. Garcia-Castro, R., Arino, M. A., \& Canela, M. A. (2009). Does social performance really lead to financial performance? Accounting for Endogeneity. Journal of Business Ethics, 92(1), 101-126. DOI: 10.1007/s10551-009-0143-8.

14. Global Reporting Initiative (2019). About sustainability reporting. Dostupno na: https://www.globalreporting.org/information/sustainability-reporting/Pages/default. aspx (pristupano 17. svibnja 2019.).

15. Gómez, A. (2019). Trends in Disclosing Non-Financial Information. IFAC Global Knowledge Gateway: Business Reporting. Dostupno na: https://www.ifac.org/global-knowledge-gateway/business-reporting/discussion/trends-disclosing-non-financial-information (pristupano 17. svibnja 2019.). 
16. GRI Newsletter (2016). Making the case for SME Sustainability Reporting. Dostupno na: https://www.globalreporting.org/information/news-and-press-center/Pages/Small -Business,-Big-Impact-Making-the-case-for-SME-Sustainability-Reporting.aspx (pristupano 17. svibnja 2019.).

17. Hoffmann, E., Dietsche, C., \& Hobelsberger, C. (2018). Between mandatory and voluntary: non-financial reporting by German companies. Uwf, 26, 47-63. DOI: $10.1007 /$ s00550-018-0479-6.

18. Jarque, C. M., \& Bera, A. K. (1987). A Test for Normality of Observations and Regression Residuals. International Statistical Review, 55(2), 163-172. Dostupno na: https://www.jstor.org/stable/pdf/1403192.pdf?casa_token=IgImZyjEy88AA AAA:dAM_brJepjdi9Mhrh2NeIUXV02hxz2RBr54vJukTspMnMzZY8XW74Yh-kac104oCV8zo4LvGwwpAVlipgNPXButZKhYh8bSN33JFAy7ITDcihkGXMhqH1A(pristupano 25. ožujka 2019.).

19. Kanji, G. K., \& Chopra, P. K. (2010). Corporate Social Responsibility in a Global Economy, Total Quality Management, 21(2), 119-143.

20. KPMG (2017). The KPMG Survey of Corporate Responsibility Reporting 2017. Dostupno na: https://assets.kpmg/content/dam/kpmg/xx/pdf/2017/10/kpmg-survey-ofcorporate-responsibility-reporting-2017.pdf (pristupano 3. travnja 2019.).

21. Loprevite S., Ricca B., \& Rupo D. (2018). Performance Sustainability and Integrated Reporting: Empirical Evidence from Mandatory and Voluntary Adoption Contexts. Sustainability. 10(5), 1-15. DOI: 10.3390/su10051351.

22. Osagie, E. R., Wesselink, R., Blok, V., Lans, T., \& Mulder, M. (2016). Individual Competencies for Corporate Social Responsibility: A Literature and Practice Perspective. Journal of Business Ethics, 135(2), 233-252. DOI: doi.org/10.1007/s10551014-2469-0.

23. Pizzi, S. (2018). The Relationship between Non-financial Reporting, Environmental Strategies and Financial Performance. Empirical Evidence from Milano Stock Exchange. Administrative Sciences. 8(4), 1-9. DOI: 10.3390/admsci8040076.

24. Rašić, S. (2011). Društveno odgovorno poslovanje: Motivi za uvođenje društveno odgovornog poslovanja. U: Galetić, L., ur., Organizacija velikih poduzeća. Zagreb: Sinergija-nakladništvo, 455-473.

25. Reddy, K., \& Gordon, L. W. (2010). The effect of Sustainability Reporting on Financial Performance: An Empirical Study Using Listed Companies. Journal of Asia Entrepreneurship and Sustainability, 6(2), 19-42.

26. Sierra-Garcia, L., Garcia-Benau, M. A., \& Bollas-Araya, H. M. (2018). Empirical Analysis of Non-Financial Reporting by Spanish Companies. Administrative Sciences, 8(29), 1-17.

27. Sikavica, P., Bebek, B., Skoko, H., \& Tipurić, D. (1999). Poslovno odlučivanje. Zagreb: Informator.

28. Sofian, I., \& Dumitru, M. (2017). The Compliance of the Integrated Reports Issued by European Financial Companies with the International Integrated Reporting Framework. Sustainability, 9(8), 1-16.

29. Stolowy, H., \& Paugam, L. (2018). The expansion of non-financial reporting: 
an exploratory study. Accounting and Business Research, 48(5), 525-548. DOI: 10.1080/00014788.2018.1470141.

30. Steinmeier, M., \& Stich, M. (2019). Does Sustainability Assurance Improve Managerial Investment Decisions?. European Accounting Review, 28(1), 177-209. DOI: 10.1080/09638180.2017.1412337.

31. Švigir, A. (2018). Uloga integriranog financijskog i nefinancijskog izvještavanja u donošenju poslovnih odluka. Doktorska disertacija. Zagreb: Ekonomski fakultet.

32. Švigir, A. (2016). Uloga menadžmenta u stvaranju odgovornog društveno gospodarskog okruženja. Simpozij: Poslovna etika - ima li u ekonomiji mjesta za milosrđe, Filozofsko-teološki institut Družbe Isusove, Zagreb.

33. Vrdoljak Raguž, I., \& Hazdovac, K. (2014). Društveno odgovorno poslovanje i hrvatska gospodarska praksa. Oeconomica Jadertina, 4(1), 40-58.

34. Weaver, K., F., Morales, V. C., Dunn, S. L., Godde, K., \& Weaver, P. F. (2017). An Introduction to Statistical Analysis in Research: With Applications in the Biological and Life Sciences. New Jersey: John Wiley \& Sons.

35. Zakon o provedbi Opće uredbe o zaštiti podataka, Narodne Novine, br. 42/18.

36. Zakon o računovodstvu, Narodne Novine, br. 78/15., 134/15., 120/16., 116/18.

37. Žager, K., \& Žager, L. (2006). The Role of Financial Information in Decision Making Process. Innovative Marketing, 2(3), 35-40. Dostupno na: https://businessperspectives.org/images/pdf/applications/publishing/templates/article/assets/1746/im _ en_2006_03_Zager.pdf (pristupano 17. svibnja 2019.). 